\title{
Road to exercise mimetics: targeting nuclear receptors in skeletal muscle
}

\author{
Weiwei Fan', Annette R Atkins ${ }^{1,2}$, Ruth T Yu', Michael Downes ${ }^{1}$ and Ronald M Evans ${ }^{1,2}$ \\ ${ }^{1}$ Gene Expression Laboratory ${ }^{2}$ Howard Hughes Medical Institute, Salk Institute for Biological Studies, \\ La Jolla, California 92037, USA
}

Correspondence should be addressed to R M Evans Email evans@salk.edu

\begin{abstract}
Skeletal muscle is the largest organ in the human body and is the major site for energy expenditure. It exhibits remarkable plasticity in response to physiological stimuli such as exercise. Physical exercise remodels skeletal muscle and enhances its capability to burn calories, which has been shown to be beneficial for many clinical conditions including the metabolic syndrome and cancer. Nuclear receptors (NRs) comprise a class of transcription factors found only in metazoans that regulate major biological processes such as reproduction, development, and metabolism. Recent studies have demonstrated crucial roles for NRs and their co-regulators in the regulation of skeletal muscle energy metabolism and exercise-induced muscle remodeling. While nothing can fully replace exercise, development of exercise mimetics that enhance or even substitute for the beneficial effects of physical exercise would be of great benefit. The unique property of NRs that allows modulation by endogenous or synthetic ligands makes them bona fide therapeutic targets. In this review, we present an overview of the current understanding of the role of NRs and their co-regulators in skeletal muscle oxidative metabolism and summarize recent progress in the development of exercise mimetics that target NRs and their co-regulators.
\end{abstract}

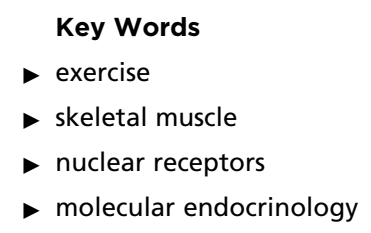

Journal of Molecular Endocrinology (2013) 51, T87-T100

\section{Introduction}

Exercise has been known for its health benefits since ancient times. It is now widely accepted that physical activity positively affects a variety of clinical conditions including obesity, type 2 diabetes, metabolic syndrome, neurodegenerative diseases, cardiovascular diseases, and cancer (Perseghin et al. 1996, Grazina \& Massano 2013, Lemanne et al. 2013, Mellett \& Bousquet 2013). On the other hand, physical inactivity has major negative influences on these disease conditions (Hu et al. 2004).

How exactly exercise exerts its beneficial effects is not fully understood; however, skeletal muscle is believed to play a vital role (Hamilton \& Booth 2000). As the largest organ in the human body, skeletal muscle comprises $\sim 40 \%$ of total body mass and accounts for $\sim 30 \%$ of whole-body energy metabolism during rest (Zurlo et al.
1990). Upon insulin stimulation, skeletal muscle can be responsible for $\sim 85 \%$ of total glucose disposal (Defronzo et al. 1981). During peak activity, whole-body energy metabolism can be increased by up to 20 -fold, 90\% of which is contributed by skeletal muscle (Zurlo et al. 1990). Hence, muscle is the major site of calorie burning of energy substrates such as glucose and free fatty acids. Exercise training remodels skeletal muscle to more efficiently clear these substrates, the excess levels of which negatively affect many tissues.

In mammals, skeletal muscle is a mosaic of heterogeneous myofibers with diverse structural and functional properties (Schiaffino \& Reggiani 2011). Based on the expression patterns of different myosin heavy chain (MYH) isoforms, which coincide with various biochemical

Published by Bioscientifica Ltd

This paper is one of nine papers that form part of the 25 th anniversary special issue of Journal of Molecular Endocringlogy. The Guest. Editor for this section was Ronald $M_{3}: 15: 29 \mathrm{AM}$ Evans, Investigator, Howard Hughes Medical Institute and Professor, Salk Institute for $15: 29 \mathrm{AM}$ Evar, Biological Studies, La Jolla, CA, USA. He was not involved in the handling of this paper, on which he is listed as an author 
characteristics, myofibers can be classified into four major groups: slow-twitch type I and fast-twitch types IIa, IIx/d, and IIb. Type I and IIa fibers are red in appearance due to their high myoglobin content. They are rich in mitochondria and predominantly powered by complete oxidation of glucose and fatty acids. These oxidative fibers are also dense with vasculature and resistant to fatigue. By contrast, the glycolytic type IIx/d and IIb fibers are generally white in color, have less myoglobin content and mitochondria, mainly rely on glycolysis for energy production, have less vasculature, and fatigue rapidly (Schiaffino \& Reggiani 2011). In humans, fiber-type composition is strongly associated with metabolic health, with more glycolytic fibers being seen in obese and type 2 diabetic patients (Hickey et al. 1995).

It has been well documented that skeletal muscle undergoes a series of physiological and biochemical adaptations upon exercise training (Hamilton \& Booth 2000), of which the most intriguing is fiber-type transformation. Many human and animal studies have clearly demonstrated that prolonged exercise induces the glycolytic type IIb and IIx/d fibers to transform to the more oxidative type IIa fibers (Gollnick et al. 1973, Foster et al. 1978, Wu et al. 2001). Although some professional athletes have an increased proportion of type I fibers (Gollnick et al. 1972), it remains unclear whether exercise training can switch type II fibers completely to type I. While exercise has a positive effect on the glycolytic-to-oxidative fiber-type transformation, physical inactivity and obesity usually have the opposite effect and lead to the reverse transformation (Bergouignan et al. 2011). During fibertype transformation, not only is the expression of $\mathrm{MYH}$ isoforms switched, but other fiber-type-specific properties, such as mitochondrial density, oxidative phosphorylation (OXPHOS) activity, vasculature, and fatigue resistance, are also changed accordingly (Yan et al. 2011).

Skeletal muscle adaptation during exercise involves numerous transcriptional and epigenetic changes, which are regulated by multiple signaling pathways (Bassel-Duby \& Olson 2006, Barrès et al. 2012). In addition to the widely known calcineurin/NFAT and HDAC/MEF pathways, it has recently been shown that nuclear receptors (NRs) and their co-regulatory factors also play important roles in skeletal muscle adaptation.

NRs are ligand-modulated transcription factors that respond to a variety of hydrophobic molecules including hormones, lipids, steroids, retinoids, and xenobiotics. All NRs share similar modular domains, including a highly conserved DNA-binding domain (DBD), a ligand-binding domain (LBD), variable $\mathrm{N}$ - and $\mathrm{C}$-terminal domains, and a hinge domain between the DBD and LBD (Mangelsdorf et al. 1995). The DBD is characterized by a zinc finger motif that recognizes the hormone response element on target chromatin and the LBD by a hydrophobic ligand-binding pocket. Upon ligand binding, NRs undergo conformational changes, which alter their interactions with other proteins and trigger epigenetic chromatin changes and downstream transcriptional regulation (Wurtz et al. 1996).

A major goal of exercise science is to find substitutes for physical exercise that achieve its beneficial effects in people unable to exercise. The ability of NRs to sense and respond to small-molecule ligands makes them ideal pharmacological targets. This review focuses on the roles of NRs and their co-regulatory factors in the regulation of skeletal muscle functions, including fiber-type determination, mitochondrial biogenesis, vasculature development, and fatigue resistance, with the goal of shedding some light on the development of the 'exercise in a pill'.

\section{The peroxisome proliferator-activated receptor subfamily}

The peroxisome proliferator-activated receptor (PPAR) subfamily of NRs is composed of three members: PPAR $\alpha$, $\operatorname{PPAR} \delta$ (also referred to as PPAR $\beta$ ), and PPAR $\gamma$. PPAR $\alpha$ was the first PPAR identified during a screen for the molecular target of fibrates, a class of cholesterol-lowering compounds that increase hepatic fatty acid oxidation and peroxisome proliferation (hence the name) (Issemann \& Green 1990). Based on sequence homology, PPAR $\delta$ and PPAR $\gamma$, which do not induce peroxisome proliferation, were later cloned from mouse tissue (Zhu et al. 1993, Kliewer et al. 1994).

PPARs are predominantly localized in the nucleus. They form heterodimers with retinoid X receptors (RXRs) and can be activated by both PPAR ligands and RXR ligands. In the absence of a ligand, the PPAR/RXR heterodimers bind to PPAR response elements (PPREs) in association with transcriptional co-repressors such as nuclear receptor co-repressor (NCoR) and SMRT. Ligand binding leads to a conformational change and recruitment of co-activators such as PPAR $\gamma$ co-activator $1 \alpha$ and PPAR $\gamma$ co-activator $1 \beta$ (PGC1 $\alpha$ and PGC1 $\beta$ ) to replace the co-repressors, resulting in the activation of downstream target gene expression. PPARs play essential roles in the regulation of lipid metabolism. They sense and respond to free fatty acids and their derivatives to regulate genes involved at almost all levels of lipid metabolism, including lipid import/export, synthesis, storage, breakdown, and oxidation (Evans et al. 2004). Although the PPAR

Published by Bioscientifica Ltd 
subfamily shares certain common target genes, PPAR $\alpha$ and PPAR $\delta$ are typically involved in the regulation of lipid catabolism and oxidation, while PPAR $\gamma$ is responsible for adipogenesis and lipid synthesis. All the three PPARs are expressed in skeletal muscle (Muoio et al. 2002, Amin et al. 2010), and over the last decade, both gain-of-function and loss-of-function studies have contributed significantly to our understanding of their roles in muscle.

PPAR $\delta$ is the most abundant PPAR in skeletal muscle (Muoio et al. 2002, Amin et al. 2010) and plays important roles in the regulation of fiber-type determination, mitochondrial function, lipid metabolism, and fatigue resistance (Fig. 1). It is expressed relatively highly in oxidative fibers compared to glycolytic fibers. Exercise, in both acute and prolonged forms (Luquet et al. 2003, Watt et al. 2004), induces the expression of Pparo (Ppard) in skeletal muscle. Similar to exercise, fasting also triggers a fuel-source switch in skeletal muscle from glucose to fatty acid utilization. Consistently, $6-48 \mathrm{~h}$ of fasting dramatically increases the expression of Pparo in skeletal muscle (de Lange et al. 2006).

Two independent studies have shown that the overexpression of Pparo in skeletal muscle induces a glycolytic-to-oxidative fiber-type transformation (Luquet et al. 2003, Wang et al. 2004). Mice overexpressing WT Pparo have more oxidative fibers, higher OXPHOS enzyme activities, and more uncoupling proteins (UCPs). These transgenic mice also have reduced fat content with smaller adipocyte size, similar to what is observed in exercised animals (Luquet et al. 2003). Mice expressing a constitutively active form of Pparo were nicknamed 'marathon mice' as they can run for up to twice the distance of their WT littermates. They have more type I and less type II fibers, have increased mitochondrial biogenesis and uncoupling, are resistant to diet-induced obesity, and have improved glucose tolerance (Wang et al. 2004). Conversely, conditional knockout of Pparo in skeletal muscle leads to an oxidative-to-glycolytic fiber-type switch. The knockout muscle has lower expression of genes involved in fatty acid catabolism and oxidation, as well as reduced OXPHOS activities (Schuler et al. 2006). Upon a high-fat diet challenge, the mutant mice gain more weight mainly due to increased fat content and are more susceptible to developing insulin resistance and glucose intolerance (Schuler et al. 2006). Therefore, Pparo appears to be necessary for the maintenance of oxidative
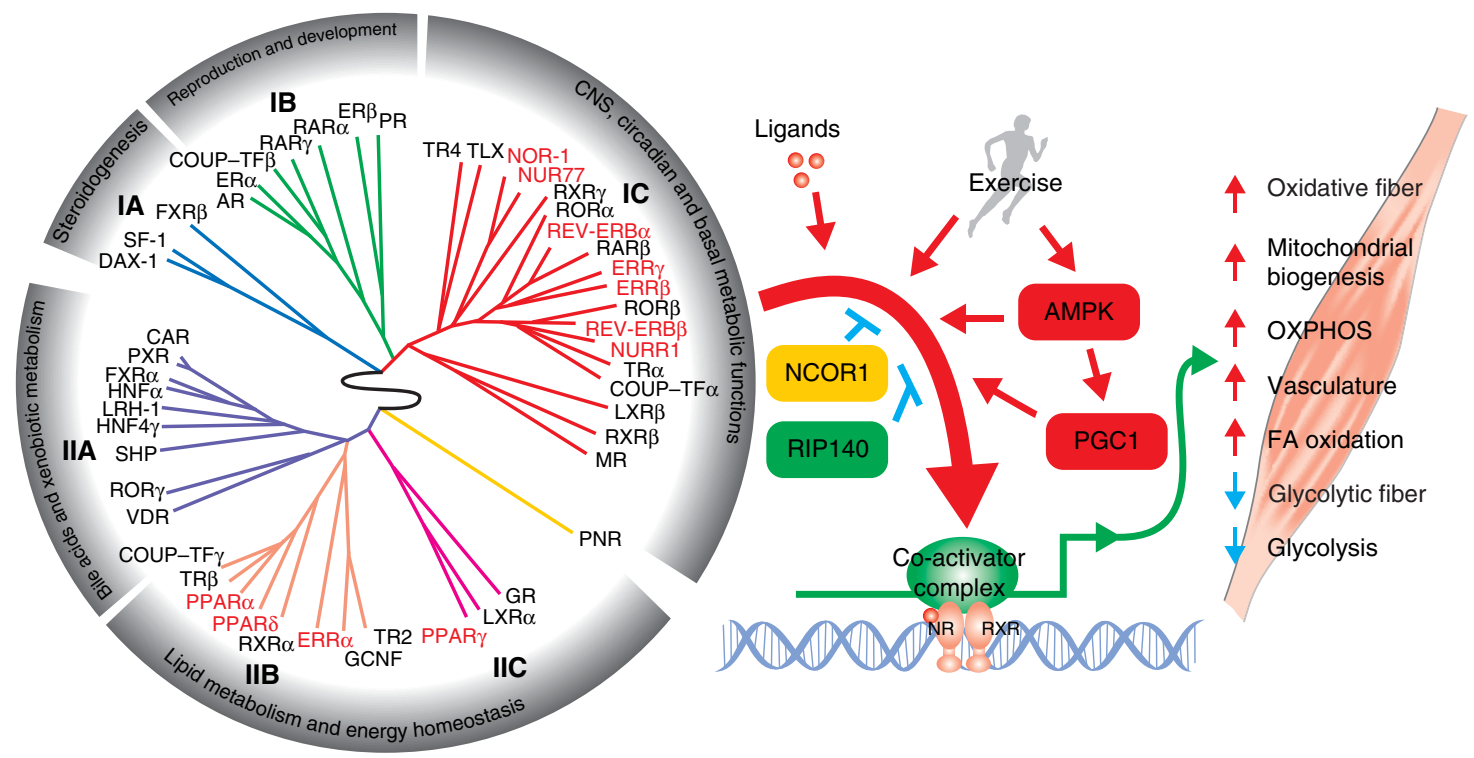

\section{Figure 1}

NR regulation of energy metabolism and remodeling in skeletal muscle. The NR ring of physiology is shown on the left (Bookout et al. 2006). It clusters 49 mouse NRs into six groups based on their tissue distribution patterns. The NRs that have been found to play crucial roles in skeletal muscle function (highlighted in red/bold) are clustered mainly in two groups: group IC, the members of which are selectively expressed in highly metabolic tissues and are involved in CNS, circadian, and basal metabolic functions, including NOR1, NUR77, NURR1, ERR $\beta, E R R \gamma$, REV-ERB $\alpha$, and
REV-ERB $\beta$, and groups IIB and IIC, the members of which are broadly expressed and are linked to lipid metabolism and energy homeostasis, including PPAR $\alpha$, PPARס, PPAR $\gamma$, and ERR $\alpha$. These NRs work in concert with exercise and co-regulators to regulate many aspects of skeletal muscle physiology. Synthetic ligands targeting NRs and their co-regulators can enhance or replace the physiological benefits induced by exercise, which is of great value to public health. http://jme.endocrinology-journals.org DOI: 10.1530/JME-13-0258
๑) 2013 Society for Endocrinology Printed in Great Britain
Published by Bioscientifica Ltd 
fibers and their oxidative functions in skeletal muscle. However, it remains to be demonstrated whether Pparo is required for exercise-induced muscle remodeling.

Ppar (Ppara) is abundantly expressed in tissues with high fatty acid catabolism, such as liver and heart (Fig. 1; Braissant et al. 1996), where it is activated by free fatty acids and promotes fatty acid oxidation (Kersten et al. 1999). Ppara is also expressed at significant levels in skeletal muscle. Both Ppar $\alpha$ and Pparo regulate fatty acid catabolism and share common target genes. Similar to Pparo, the overexpression of Ppar $\alpha$ in skeletal muscle also induces the expression of genes involved in fatty acid catabolism, tricarboxylic acid (TCA) cycle, and mitochondrial OXPHOS. As a result, fatty acid oxidation is increased in the transgenic muscle and the mice are resistant to diet-induced obesity (Finck et al. 2005). However, the transgenic mice are more prone to developing insulin resistance and glucose intolerance due to the reduced expression of genes involved in glucose uptake and glycolysis (Finck et al. 2005). Thus, although Ppar $\alpha$ has a positive role in the regulation of fatty acid oxidation in skeletal muscle, its activity needs to be finely regulated to balance glucose and fatty acid metabolism.

In addition to their different roles in metabolic regulation, Ppar $\alpha$ also functions distinctly from Ppar $\delta$ in fiber-type determination. In contrast to Ppar $\delta$, the overexpression of Ppard in skeletal muscle does not increase endurance but rather reduces it by more than $50 \%$ (Gan et al. 2011). Consistently, an oxidative-to-glycolytic fibertype switch is found in these mice, as shown by the expression of MYH genes, metachromatic ATPase staining, and MYH immunohistochemistry staining (Gan et al. 2013). The opposing functions of PPAR $\alpha$ and PPAR $\delta$ in the induction of glycolytic and oxidative fiber-type transformations respectively seem to be mediated by a miRNA network involving two specific miRNAs, miR-208b and miR-499 (Gan et al. 2013), which play important roles in fiber-type determination by activating the oxidative and repressing the glycolytic myofiber gene program (van Rooij et al. 2009). In contrast to the overexpression model, knockout of Ppar $\alpha$ in skeletal muscle induces a glycolyticto-oxidative fiber-type switch (Gan et al. 2013). Therefore, endogenous PPAR $\alpha$ counteracts PPAR $\delta$ to maintain a proper fiber-type composition in skeletal muscle.

Ppary (Pparg) is expressed most highly in adipose tissues, where it plays an essential role in adipogenesis and whole-body lipid homeostasis (Fig. 1). Its ablation in adipose tissues leads to severe lipodystrophy and elevated levels of blood triglycerides and free fatty acids. The knockout mice are more susceptible to diet-induced insulin resistance. However, treatment with thiazolidinediones (TZDs), a class of PPAR $\gamma$-specific ligands, can still improve insulin sensitivity in these knockout mice, suggesting that PPAR $\gamma$ in non-adipose tissues also contributes to its regulation of lipid homeostasis and insulin sensitivity (He et al. 2003). The strongest evidence showing a positive role for muscle PPAR $\gamma$ in metabolic regulation comes from the generation of a mouse model with Ppary specifically deleted in skeletal muscle (Hevener et al. 2003). These knockout mice develop glucose intolerance and insulin resistance. Moreover, they are less responsive to TZD-induced skeletal muscle insulin sensitization, while the effects of TZDs in the liver and adipose tissues remain unaffected (Hevener et al. 2003). A similar study seems to have drawn a different conclusion, showing that the knockout mice only have mild insulin resistance and respond normally to TZD treatment (Norris et al. 2003). However, the two studies were carried out in mice with different genetic backgrounds, one being a pure C57BL/6J background (Hevener et al. 2003) and the other a mixed 129/sv, C57BL/6, and FVB background, which might account for the different phenotypes observed. In addition to the knockout models, the overexpression of Ppary in skeletal muscle also demonstrates its importance in metabolic regulation (Amin et al. 2010). These transgenic mice are protected from diet-induced insulin resistance and glucose intolerance. Interestingly, these mice produce significant amounts of adiponectin in skeletal muscle, despite their reduced intramuscular adiposity. Furthermore, the activation of AMP-activated protein kinase (AMPK), a known adiponectin target, in the transgenic muscle suggests that the increased adiponectin functions locally. Similar to Pparo, the overexpression of Ppary induces a glycolytic-to-oxidative fiber-type switch and an increase in mitochondrial gene expression, which may be a secondary effect from the activated AMPK pathway (Amin et al. 2010). Therefore, PPAR $\gamma$ is required in skeletal muscle for glucose and lipid homeostasis. In addition, its role in the generation of muscle adiponectin provides another layer of metabolism regulation.

\section{The estrogen-related receptor subfamily}

The estrogen-related receptor (ERR) subfamily includes three members: $\operatorname{ERR} \alpha, \operatorname{ERR} \beta$, and $\operatorname{ERR} \gamma$. ERR $\alpha$ was the first to be identified based on its high sequence homology with the estrogen receptor $\alpha(E R \alpha$; Giguère et al. 1988). ERR $\beta$ was cloned in the same study using Err (Esrra) cDNA as a probe (Giguère et al. 1988). Last but not least, ERR $\gamma$ was discovered in three independent studies using different

Published by Bioscientifica Ltd 
strategies (Eudy et al. 1998, Hong et al. 1999, Heard et al. 2000). Although all the three ERRs share high structural similarities with ERs at both the DNA and protein levels, they are distinct from ERs in both their functions and their regulation of target gene transcription (Eichner \& Giguere 2011).

All the three ERRs are believed to be constitutively active and, to date, no natural ligand(s) has been identified (Eichner \& Giguere 2011). Instead, the transcriptional activities of ERRs are regulated by a number of co-regulatory factors, the most studied of which include the steroid receptor co-activators (SRC1, SRC2, and SRC3; Hong et al. 1999, Xie et al. 1999, Zhang \& Teng 2000), the PGC1 $\alpha$ and PGC $\beta$ (Huss et al. 2002, Kamei et al. 2003), and the NR co-repressors RIP140 (receptor-interacting protein 140) and NCoR1 (Sanyal et al. 2004, Pérez-Schindler et al. 2012).

Extensive studies in the past decade have clearly established a central role of ERRs in the regulation of energy metabolism (Eichner \& Giguere 2011), which is further supported by their tissue expression patterns. Err $\alpha$ is the most abundant of the three. It is ubiquitously expressed but peaks in tissues with high energy needs including brain, heart, muscle, and kidney (Fig. 1; Giguère et al. 1988, Bookout et al. 2006). Errß (Esrrb) and Erry (Esrrg) have similar tissue distribution patterns. Both are selectively expressed in metabolically active tissues such as retina, spinal cord, heart, muscle, and kidney, with Err $\gamma$ generally being expressed at a higher level (Fig. 1; Bookout et al. 2006). All the three ERRs are highly expressed in skeletal muscle, and their roles in the regulation of muscle energy metabolism have been explored in both gain-of-function and loss-of-function studies (Luo et al. 1997, 2003, Huss et al. 2004, Wende et al. 2005, Alaynick et al. 2007, Chinsomboon et al. 2009, Rangwala et al. 2010, Narkar et al. 2011, Gan et al. 2013, Matsakas et al. 2013).

Studies of ERR $\alpha$ in skeletal muscle have mainly focused on its synergistic interaction with PGC1 $\alpha$ in target gene regulation. No phenotypic change in skeletal muscle is observed after whole-body Err $\alpha$ ablation, possibly due to a compensatory induction of Pgc1 $\alpha$ (Ppargc1a; Luo et al. 2003, Huss et al. 2004). ERR $\alpha$ seems to play a role in the regulation of fatty acid metabolism and fuel selection in skeletal muscle as its overexpression induces the expression of Ppara, a key regulator of fatty acid metabolism, and $P d k 4$, the mitochondrial gate keeper for pyruvate oxidation. The overexpression of its co-activator PGC1 $\alpha$ can further enhance the expression of these genes (Huss et al. 2004, Wende et al. 2005). Such regulation is mediated by the direct binding of ERR $\alpha$ to the ERR response element (ERRE) on the promoters of Ppara and
Pdk4 (Huss et al. 2004, Wende et al. 2005). In addition, $\mathrm{ERR} \alpha$ also regulates myocyte differentiation. The overexpression of Err $\alpha$ in $\mathrm{C} 2 \mathrm{C} 12$ myoblasts accelerates myotube formation, while Err $\alpha$-null primary myocytes show delayed myogenesis and mitochondrial dysfunction (Murray \& Huss 2011). Although ERR $\alpha$ positively regulates lipid metabolism and mitochondrial OXPHOS in cooperation with PGC1 $\alpha$ in heart and brown adipose tissue (Dufour et al. 2007, Villena et al. 2007), its physiological function in skeletal muscle remains to be elucidated.

Similar to ERR $\alpha$, ERR $\gamma$ also plays an important role in the regulation of energy metabolism. Err $\gamma$-null mice die within the first week of life, possibly from heart failure due to disrupted mitochondrial energy production (Alaynick et al. 2007). The importance of ERR $\gamma$ in energy metabolism is also indicated by its distribution in skeletal muscle, where it is exclusively expressed in oxidative muscles such as soleus and red gastrocnemius but not in glycolytic muscles such as white gastrocnemius or quadriceps (Narkar et al. 2011). Transgenic mice with muscle-specific overexpression of Erry have a remarkable conversion of glycolytic to oxidative fibers, with all white muscles appearing red (Narkar et al. 2011). The transgenic mice are fatigue resistant and can run about twice the distance of the controls. They also have a higher energy expenditure rate and a lower respiratory exchange ratio (RER), indicating a fuel preference for fatty acids. Both mitochondrial biogenesis and vascularization are induced. Gene expression analysis has further revealed a gene signature change from glycolytic to oxidative muscles, including the induction of genes involved in lipid metabolism, TCA cycle, angiogenesis, and mitochondrial OXPHOS (Rangwala et al. 2010, Narkar et al. 2011). In addition, the overexpression of ERR $\gamma$ also alleviates the symptoms of Duchenne muscular dystrophy and promotes muscle recovery from ischemic damage (Matsakas et al. 2012, 2013). Therefore, genetic activation of ERR $\gamma$ can induce an exercise-like phenotype in skeletal muscle with positive impacts on muscle diseases. However, its endogenous roles in the regulation of skeletal muscle function and exercise-induced muscle remodeling remain to be demonstrated.

Unlike ERR $\alpha$ and ERR $\gamma$, little is known about whether and how ERR $\beta$ regulates energy metabolism. Loss-offunction studies have demonstrated the crucial roles of ERR $\beta$ in placental development (Luo et al. 1997), germ cell development (Mitsunaga et al. 2004), inner ear development (Chen \& Nathans 2007), and retinal photoreceptor survival (Onishi et al. 2010). In skeletal muscle, it has been briefly shown that both ERR $\beta$ and ERR $\gamma$ are required to

Published by Bioscientifica Ltd 
maintain type I muscle fibers in the oxidative/glycolytic mixed muscle gastrocnemius but not in the mostly oxidative muscle soleus (Gan et al. 2013). However, the extent of functional redundancy between ERR $\beta$ and ERR $\gamma$ in skeletal muscle is unclear, and more work is needed to fully understand the role of ERR $\beta$ in the regulation of energy metabolism and skeletal muscle function.

\section{The NR4A subfamily}

The NR4A subfamily of NRs consists of three closely related members: NR4A1 (NUR77), NR4A2 (NURR1), and NR4A3 (NOR1). Similar to ERRs, the NR4As are also orphan receptors that do not bind to any natural agonist (Pearen \& Muscat 2010). They are constitutively active and their transcriptional activities appear to be primarily regulated by their abundance and post-translational modifications (Chao et al. 2012).

Based on their tissue expression patterns, the NR4As are clustered in the same group as ERR $\beta$ and ERR $\gamma$; they are preferentially expressed in tissues with high energy needs such as brain, muscle, and brown adipose tissue (Fig. 1; Bookout et al. 2006). While little is known about the function of NURR1 in skeletal muscle, both NUR77 and NOR1 have been clearly shown to play important roles in the regulation of skeletal muscle metabolism (Maxwell et al. 2005, Chao et al. 2007, 2012, Pearen et al. 2008, 2012).

In skeletal muscle, Nur77 is selectively expressed in glycolytic vs oxidative muscles, suggesting a positive role in the regulation of glucose metabolism (Chao et al. 2007). The expression of NUR77 can be significantly induced by $\beta$-adrenergic signaling from the sympathetic nervous system to regulate muscle energy metabolism (Maxwell et al. 2005). Contrarily, skeletal muscle denervation reduces the expression of NUR77, as well as a subset of glucose metabolism genes, which is restored by the ectopic expression of Nur77 in denervated muscle (Chao et al. 2007). The importance of NUR77 in the regulation of glucose metabolism can be further demonstrated by the overexpression of Nur77 in $\mathrm{C} 2 \mathrm{C} 12$ cells, which not only induces glucose metabolism genes but also enhances cellular glucose transport (Chao et al. 2007). Despite its role in the regulation of glucose metabolism, musclespecific overexpression of Nur77 induces an oxidative fiber-type switch, similar to Pparo and Erry (Chao et al. 2012). The transgenic muscle has typical characteristics of oxidative fibers such as increased fatty acid oxidation, higher mitochondrial OXPHOS activity, and fatigue resistance. However, the level of glycogen, which is usually high in glycolytic fibers and low in oxidative fibers, is increased in the Nur77 transgenic muscle, suggesting a different working model for its fiber-type determination compared with PPAR $\delta$ and ERR $\gamma$. More detailed analysis of fiber-type composition, endurance performance, and gene expression profiling will be required to understand the mechanism of muscle remodeling induced by NUR77. In addition, the endogenous role of NUR77 in the $\beta$-adrenergic signaling cascade remains to be elucidated.

Similar to Nur77, Nor1 is also induced by $\beta$-adrenergic signaling in skeletal muscle (Pearen et al. 2008). However, NOR1 seems to participate more in the regulation of fatty acid metabolism rather than in that of glucose. Knockdown of NOR1 in C2C12 cells reduces fatty acid oxidation and mitochondrial OXPHOS, but induces glycolysis (Pearen et al. 2008). The overexpression of an active form of Nor1 in skeletal muscle leads to a fiber-type switch from glycolytic to oxidative fibers (Pearen et al. 2012). The transgenic mice have increased running endurance, improved insulin sensitivity and glucose tolerance, and higher energy expenditure. Both myoglobin expression and mitochondrial activity are induced in the transgenic muscle. The fiber-type switch phenotype seems to be dependent on muscle groups, with overall more type IIa and IIx fibers but less type I and IIb fibers. This intermediate oxidative fiber-type switch might be due to the enhanced HDAC5 activity, which has been shown to promote oxidative fiber formation (Potthoff et al. 2007). However, the direct targets of NOR1 remain to be identified. It is also not clear how NOR1 activates HDAC5 and whether or not other pathways are involved in the fiber-type conversion induced by NOR1.

\section{The REV-ERB subfamily}

There are two members in the REV-ERB subfamily of NRs: REV-ERB $\alpha$ and REV-ERB $\beta$. REV-ERBs were originally discovered as orphan receptors (Miyajima et al. 1989), but were later 'adopted' by the identification of heme as their physiological ligand (Raghuram et al. 2007). Upon heme binding, REV-ERBs recruit co-repressors such as NCoR1 and repress target gene expression (Raghuram et al. 2007, Yin et al. 2007). REV-ERBs are active components of the circadian clock (Preitner et al. 2002, Bass 2012), and recent studies have also linked their functions to metabolic regulation in adipose tissues, liver, and muscle (Yang et al. 2006, Kumar et al. 2010, Cho et al. 2012, Woldt et al. 2013). Anatomical profiling of NRs clusters REV-ERBs in the same group as ERR $\beta, E R R \gamma$, NUR77, and NOR1, all of

Published by Bioscientifica Ltd 
which are preferentially expressed in metabolically active tissues (Fig. 1; Bookout et al. 2006). This further indicates an active role of REV-ERBs in the regulation of energy metabolism.

While little is known about the function of REV-ERB $\beta$ in skeletal muscle, REV-ERB $\alpha$ has recently been shown to positively regulate energy metabolism and mitochondrial OXPHOS function in muscle (Woldt et al. 2013). Rev-erb $\alpha$ (Nr1d1) is expressed at higher levels in oxidative muscles than in glycolytic muscles and exercise can further induce its expression (Woldt et al. 2013). The importance of REV-ERB $\alpha$ in skeletal muscle has been demonstrated in Rev-erb $\alpha$-null mice. These mice have reduced voluntary wheel-running activity, diminished endurance exercise performance, and lower energy expenditure during exercise. The knockout muscle has decreased mitochondrial density, reduced OXPHOS activity, and downregulated fatty acid metabolism genes (Woldt et al. 2013). On the other hand, the overexpression of Rev-erb $\alpha$ in $\mathrm{C} 2 \mathrm{C} 12$ cells increases mitochondrial biogenesis and OXPHOS activity, accompanied by the induction of fatty acid metabolism genes. The in vivo overexpression of Rev-erb $\alpha$ in muscle via adeno-associated viral (AAV) infection also induces mitochondrial OXPHOS activity. These physiological changes seem to be mediated by the AMPK-Sirt1-PGC1 $\alpha$ signaling pathway, which is downregulated in the knockout muscle but upregulated in Rev-erb $\alpha$-overexpressing muscle cells. In addition to its roles in the regulation of mitochondrial biogenesis and OXPHOS activity, muscle REV-ERB $\alpha$ is also involved in the modulation of mitochondrial autophagy (mitophagy, Woldt et al. 2013). Mitophagy is induced in Rev-erb $\alpha$ knockout muscle but suppressed in overexpressing C2C12 cells. REV-ERB $\alpha$ seems to directly bind to and repress genes in multiple steps of mitophagy, including the mitophagy regulator Park2, the autophagosome initiation factor Ulk1, the autophagosome elongation factors Atg5 and Bnip3, and the lysosomal enzymes Ctsl and Atpase6v1b2. Therefore, REV-ERB $\alpha$ increases mitochondria number by both inducing mitochondrial biogenesis through the AMPKSirt1 pathway and reducing mitochondrial turnover by inhibiting mitophagy. However, it is not clear how AMPK is activated by the overexpression of Rev-erb $\alpha$ since the level of ATP is much lower in Rev-erb $\alpha$-knockout muscle (Woldt et al. 2013), which is usually associated with AMPK activation. Also, the inhibition of mitophagy might be deleterious in the long term due to the diminished clearance of dysfunctional mitochondria (Narendra et al. 2008, Jin \& Youle 2012).

\section{NR co-regulatory factors}

The functions of NRs are finely modulated by associated co-activators and co-repressors. The abundance of these co-regulators and their post-translational modifications are regulated in response to a variety of physiological stimuli such as exercise and fasting, which then induce conformational changes in the NR-chromatin complexes and regulate their transcriptional activities. Recent studies have demonstrated important roles for NR co-regulators in energy metabolism and fiber-type determination in skeletal muscle.

\section{PPAR $\gamma$ co-activator 1}

The PGC1 $\alpha$ and PGC1 $\beta$ are probably the best-known and most studied NR co-regulators implicated in energy metabolism. Both are highly expressed in metabolically active tissues such as brain, heart, muscle, and brown adipose tissue, where they serve as co-activators for a number of transcription factors involved in the regulation of energy metabolism, including the PPAR and ERR NRs, and the nuclear respiratory factors 1 and 2 (NRF1 and NRF2/GABPA).

PGC1 $\alpha$ was first identified as a cold-inducible thermogenic factor in brown adipose tissue (Puigserver et al. 1998). In skeletal muscle, $P g c 1 \alpha$ is predominantly expressed in oxidative muscles such as soleus (Wu et al. 1999). The expression of $P g c 1 \alpha$ can be induced by exercise or cold exposure in skeletal muscle (Puigserver et al. 1998, Baar et al. 2002, Russell et al. 2003). In addition to expression level, its co-transcriptional activity can also be modulated by a variety of post-translational modifications such as phosphorylation (Puigserver et al. 2001, Jäger et al. 2007), acetylation (Rodgers et al. 2005), and methylation (Teyssier et al. 2005). When overexpressed in $\mathrm{C} 2 \mathrm{C} 12$ muscle cells, Pgc1 $\alpha$ stimulates mitochondrial biogenesis by upregulating the mitochondrial transcription factor A (Tfam) as well as the mitochondrial regulators $\mathrm{Nrf1}$ and $\mathrm{Nrf2}$ ( $\mathrm{Nfe} 2 \mathrm{l2}$ ). It can further function as a co-activator for NRF1 and NRF2 in the upregulation of the expression of mitochondrial genes. In addition to mitochondrial biogenesis, $\operatorname{Pgc} 1 \alpha$ also stimulates mitochondrial uncoupling by upregulating the mitochondrial $U c p 2$, to further enhance mitochondrial energy expenditure (Wu et al. 1999). In vivo ectopic expression of $P g c 1 \alpha$ in skeletal muscle not only induces mitochondrial biogenesis and OXPHOS activity but also switches type IIb and IIx/d glycolytic fibers to type I and IIa oxidative fibers (Lin et al. 2002b). As a result, the transgenic mice have improved endurance running performance

Published by Bioscientifica Ltd 
(Calvo et al. 2008). Loss-of-function studies, both wholebody and muscle-specific, have shown that $P g c 1 \alpha$ is required for proper mitochondrial OXPHOS and energy metabolism in skeletal muscle (Leone et al. 2005, Handschin et al. 2007). However, fiber-type composition and exercise-induced fiber-type switches are not affected by the knockout of Pgc1 1 (Geng et al. 2010). On top of that, a recent study has shown that muscle mitochondrial biogenesis can still be induced by exercise without $P g c 1 \alpha$ (Rowe et al. 2012), suggesting an alternate signaling pathway in remodeling skeletal muscle upon exercise induction.

PGC1 $\beta$ was identified by its high homology with PGC1 $\alpha$ (Kressler et al. 2002, Lin et al. 2002a). It is also highly involved in the regulation of mitochondrial function and energy metabolism (Kamei et al. 2003). In vitro overexpression of $P g c 1 \beta$ (Ppargc $1 b)$ in muscle cells has effects similar to that of $P g c 1 \alpha$ in terms of promoting mitochondrial biogenesis and oxidative fiber-type transformation (Mortensen et al. 2006). Similarly, the overexpression of $P g c 1 \beta$ in skeletal muscle stimulates mitochondrial OXPHOS and fatty acid oxidation, along with oxidative fiber-type transformation (Arany et al. 2007). However, instead of a switch toward the most oxidative type I and IIa fibers as seen in the PGC1 $\alpha$ model, PGC1 $\beta$ induces a more intermediate switch toward type IIx/d fibers (Arany et al. 2007), suggesting a different working mechanism. Whole-body or muscle-specific knockout of $P g c 1 \beta$ causes reduced mitochondrial OXPHOS function in skeletal muscle but does not change fiber-type composition (Lelliott et al. 2006, Sonoda et al. 2007, Zechner et al. 2010). It would be expected that PGC1 $\alpha$ and PGC1 $\beta$ compensate for each other when one is absent. This is true for their contributions to the regulation of mitochondrial function. Double-knockout mice lacking $P g c 1 \alpha$ and $P g c 1 \beta$ in skeletal muscle have significantly lower mitochondrial OXPHOS activity compared with the single-knockout mice. However, the fiber-type composition of the double-knockout mice is not different from that of the WT controls (Zechner et al. 2010). Therefore, PGC1 $\alpha$ and PGC1 $\beta$ are necessary for mitochondrial OXPHOS function in skeletal muscle, but appear dispensable for oxidative fiber-type determination.

\section{Receptor-interacting protein 140}

In addition to the co-activators of NRs, their co-repressors also contribute to the regulation of energy metabolism in skeletal muscle, one of which is the RIP140. It was originally identified as a co-regulatory factor for the ERs
(Cavaillès et al. 1995). RIP140 (NRIP) is highly expressed in metabolic tissues such as fat and muscle (Leonardsson et al. 2004). In skeletal muscle, it is selectively expressed in glycolytic vs oxidative muscles (Seth et al. 2007), indicating a repressive role in the regulation of oxidative metabolism. Rip140-null mice exhibit $\sim 70 \%$ reduction in total fat content, mainly due to increased fatty acid oxidation and mitochondrial energy consumption in muscle and white adipose tissue (Leonardsson et al. 2004). The knockout mice exhibit $\sim 25 \%$ increase in whole-body energy expenditure and a lower RER, suggesting a shift toward fat utilization as energy source. In primarily glycolytic muscles where Rip140 is endogenously expressed, loss of Rip140 induces an oxidative fiber-type switch toward type IIa and IIx/d fibers, as well as increases in myoglobin content and mitochondrial biogenesis. Gene expression profiling further reveals significant induction of genes involved in fatty acid oxidation and mitochondrial OXPHOS in the knockout muscle (Seth et al. 2007). On the contrary, ectopic expression of Rip140 in oxidative muscles causes a reduction of oxidative fibers and myoglobin content. However, the exercise-induced fibertype conversion is still retained in these transgenic mice (Seth et al. 2007). A subset of oxidative genes repressed by RIP140 are known targets of PPARs and ERRs and can be co-activated by PGC1 $\alpha$, including Mcad (Cdh15), Cidea, Cpt1b, and Fabp3 (Christian et al. 2006, Hallberg et al. 2008). Additionally, RIP140 is recruited to either known or predicted PPREs and ERREs at the promoters of these genes (Seth et al. 2007). Hence, RIP140 and PGC1 could work in a yin-yang fashion in the regulation of the transcriptional activity of NRs such as PPARs and ERRs.

\section{Nuclear receptor co-repressor 1}

The NCoR1 was first identified as a ligand-independent transcriptional co-repressor for thyroid hormone receptor and retinoic acid receptor (Hörlein et al. 1995). It is ubiquitously expressed and is required for normal embryonic development (Jepsen et al. 2000). In skeletal muscle, NCoR1 is expressed at similar levels in oxidative and glycolytic muscles (Schuler et al. 1999). However, in conditions when fatty acid metabolism is stimulated, such as during fasting, high-fat diet challenge, and exercise, its expression in skeletal muscle is significantly reduced (Yamamoto et al. 2011, Pérez-Schindler et al. 2012), indicating that NCoR1 is involved in the repression of fatty acid metabolism. Muscle-specific deletion of NCoR1 increases muscle mass and exercise endurance (Yamamoto et al. 2011). The Ncor1-null mice have higher locomotor

Published by Bioscientifica Ltd 
activity and whole-body energy expenditure. Similar to the overexpression of $P g c 1 \alpha$ or deletion of Rip140, the knockout of Ncor1 induces an oxidative fiber-type switch, associated with increased mitochondrial biogenesis and enhanced oxidative metabolism. In addition, there is a high overlap between the genes induced by the overexpression of Pgc1 $\alpha$ and knockout of Ncor1 or Rip140 in skeletal muscle. Similar to RIP140, NCoR1 functions through PPARs and ERRs in opposition to PGC1 $\alpha$. It is recruited to PPREs or ERREs at their target gene promoters to repress their transcriptional activity, which can be antagonized by PGC1 $\alpha$ (Christian et al. 2006, Pérez-Schindler et al. 2012). Thus, the three co-regulatory factors work cooperatively with PPARs and ERRs in the regulation of skeletal muscle adaptation and energy metabolism. However, the abundance of NCoR1 and PGC1 $\alpha$, but not of RIP140, fluctuates in response to exercise, suggesting that they both play an important role in the exertion of exercise-induced muscle remodeling (Frier et al. 2011).

\section{AMP-activated protein kinase}

The AMPK is a central mediator of metabolism that functions by sensing and regulating cellular energy supplies. It is activated when energy levels are low to restore energy balance by promoting catabolism and inhibiting anabolism (Hardie 2007). In skeletal muscle, the activity of AMPK is significantly higher in oxidative vs glycolytic muscles, indicating its contribution to the maintenance of the basal oxidative metabolism (Narkar et al. 2011). This is further confirmed by the in vivo overexpression of an inactive form of AMPK in skeletal muscle, which dramatically reduces endurance exercise capacity and induces insulin resistance and glucose intolerance (Fujii et al. 2007, 2008). In addition to the basal oxidative metabolism, the activation of AMPK is also required for exercise-induced mitochondrial biogenesis via PGC1 $\alpha$ (Zong et al. 2002, Jäger et al. 2007), in which AMPK is activated by exercise and directly phosphorylates PGC1 $\alpha$ and upregulates its co-transcriptional activity (Jäger et al. 2007, Narkar et al. 2008). In some NR genetic models where oxidative fiber-type conversion is induced, such as the muscle-specific overexpression of Pparo, Ppar Erry, or Rev-erb $\alpha$, AMPK activity is also significantly increased (Narkar et al. 2008, 2011, Amin et al. 2010, Woldt et al. 2013). Furthermore, direct interaction between AMPK and PPAR $\delta$ has been observed to synergistically activate target genes involved in oxidative metabolism (Narkar et al. 2008, Gan et al. 2011). Thus, although AMPK is not a canonical NR co-regulator, it interacts with NRs and is highly involved in their regulation of energy metabolism (Fan et al. 2011).

\section{Road to exercise mimetics}

A common feature of NRs and AMPK is that their activities can be modulated by small-molecule ligands, which makes them ideal pharmacological targets. Toward this end, a number of synthetic ligands have been developed for NRs including the ones described above. Some of these ligands have already been shown to promote skeletal muscle oxidative metabolism, including the PPAR $\delta$ agonist GW501516 (Narkar et al. 2008), ERR $\beta / \gamma$ agonist GSK4716 (Rangwala et al. 2010), and REV-ERB $\alpha / \beta$ agonists SR9009 and SR9011 (Woldt et al. 2013).

GW501516 was originally developed as a potent and selective PPAR $\delta$ agonist (Oliver et al. 2001). Its activation of PPAR $\delta$ in cultured $\mathrm{C} 2 \mathrm{C} 12$ muscle cells induces the expression of genes involved in fatty acid catabolism, mitochondrial OXPHOS, and cholesterol efflux (Dressel et al. 2003). GW501516 also works in vivo to enhance oxidative metabolism in skeletal muscle. Oral doses of $5 \mathrm{mg} / \mathrm{kg}$ per day for 4 weeks have been shown to significantly upregulate oxidative genes such as $U c p 3$, $P d k 4$, and Cpt1a, similar to that seen with the musclespecific overexpression of Pparo (Luquet et al. 2003, Wang et al. 2004, Narkar et al. 2008). The ligand activation of PPAR $\delta$ alone does not stimulate any oxidative fiber-type switch or mitochondrial biogenesis in skeletal muscle, which is different from the muscle overexpression model. However, when co-administered with exercise training, GW501516 treatment increases the proportion of type I oxidative fibers by $\sim 38 \%$ and mitochondrial biogenesis by $\sim 50 \%$, while training alone has little effect. In addition, the pairing of GW501516 treatment with exercise training has been shown to dramatically increase endurance running performance compared with GW501516 treatment or training alone. Gene expression profiling has revealed a unique oxidative gene signature, which is also found in the Pparo transgenic muscle but not during either GW501516 treatment or training alone (Wang et al. 2004, Narkar et al. 2008). Thus, in vivo activation of PPAR $\delta$ by oral administration of GW501516 enhances the effect of exercise training.

GSK4716 was identified as a specific agonist for ERR $\beta$ and ERR $\gamma$, without any crossover activity with the ERs (Zuercher et al. 2005). It seems to have good potential for promoting oxidative metabolism in skeletal muscle. In primary mouse myotubes, treatment with GSK4716 leads

Published by Bioscientifica Ltd 
to the upregulation of all the three Err genes and their co-activators $P g c 1 \alpha$ and $P g c 1 \beta$. Additionally, it induces the expression of genes involved in fatty acid oxidation, TCA cycle, and mitochondrial OXPHOS, such as Cpt1b, Idh3, and $A t p 5 b$. It also stimulates mitochondrial biogenesis as both the mitochondrial citrate synthase activity and the amount of cytochrome c are increased (Rangwala et al. 2010). However, no in vivo trial has been reported and more functional studies will be needed to fully assess its effect in skeletal muscle.

The synthetic REV-ERB agonists SR9009 and SR9011 have been developed recently (Solt et al. 2012). Treatment with SR9009 or SR9011 increases the transcriptional repression of REV-ERBs on their target genes. In vivo, a single injection of SR9009 or SR9011 has been shown to result in the induction of genes involved in glycolysis, fatty acid catabolism, and mitochondrial OXPHOS, including Hk1, Pkm2, Pgc1 $\alpha, C p t 1 b$, Fatp1, and Ucp3. Mice treated with SR9011 for 12 days have increased energy expenditure with no change in RER, indicating that the oxidation of both fatty acids and glucose is induced. Additionally, 30 days of treatment with SR9009 has been found to significantly increase mouse running endurance. In C2C12 myotubes, treatment with SR9009 or SR9011 has been reported to increase mitochondria number (Woldt et al. 2013). While the effects of these agonists on skeletal muscle seem promising, questions regarding the requirement for skeletal muscle REV-ERBs and how REV-ERBs activate energy metabolism genes remain to be answered.

In addition to the NR ligands, the AMPK activator AICAR also works as an exercise mimetic (Narkar et al. 2008). AICAR treatment for 4 weeks increases mouse energy expenditure and enhances running endurance by $\sim 40 \%$. It induces the expression of a number of genes linked to oxidative metabolism, including $S c d 1, P d k 4$, Fasn, Lipe, and Dgat, most of which are also induced by the overexpression of Pparo in skeletal muscle (Wang et al. 2004). The stimulation of oxidative genes by AICAR seems to be dependent on PPAR $\delta$ as AICAR fails to induce these genes in Pparo-null muscle cells. In addition, when administered together, AICAR and GW501516 synergistically activate PPAR $\delta$ target genes such as Ucp3, $P d k 4$, and $L p l$ (Narkar et al. 2008). Therefore, the activation of AMPK by its activator AICAR induces an oxidative gene signature change mediated by PPAR $\delta$, which causes skeletal muscle remodeling and enhances endurance. However, the mechanism as to how AMPK synergistically activates PPAR $\delta$ target genes remains to be elucidated.

\section{Conclusions}

Studies over the past decade have made it clear that NRs and their co-regulators are key regulatory components of energy metabolism and exercise-induced remodeling in skeletal muscle. Synthetic ligands targeting NRs and their co-regulators, including GW501516, AICAR, GSK4716, and SR9009/9011, have been developed and proven to be effective in enhancing or mimicking exercise effects. To date, many issues remain with the current generation of exercise mimetics, such as toxicity, side effects, and high dosage, which prevent their immediate clinical applications. However, with advances in our understanding of the molecular mechanism by which NRs regulate skeletal muscle physiology, we are optimistic that the next generation of exercise mimetics is not far away.

Declaration of interest

The authors declare that there is no conflict of interest that could be perceived as prejudicing the impartiality of the review reported.

\section{Funding}

This work was supported by US National Institutes of Health grant numbers (DK057978, DK090962, HL088093, HL105278, CA014195, and ES010337), the Glenn Foundation for Medical Research, the Leona M and Harry B Helmsley Charitable Trust, Ipsen/Biomeasure, and the Ellison Medical Foundation.

\section{Acknowledgements}

The authors thank L Ong and C Brondos for administrative assistance. RM Evans is an Investigator of the Howard Hughes Medical Institute at the Salk Institute and March of Dimes Chair in Molecular and Developmental Biology.

\section{References}

Alaynick WA, Kondo RP, Xie W, He W, Dufour CR, Downes M, Jonker JW, Giles W, Naviaux RK, Giguère V et al. 2007 ERR $\gamma$ directs and maintains the transition to oxidative metabolism in the postnatal heart. Cell Metabolism 6 13-24. (doi:10.1016/j.cmet.2007.06.007)

Amin RH, Mathews ST, Camp HS, Ding L \& Leff T 2010 Selective activation of PPAR $\gamma$ in skeletal muscle induces endogenous production of adiponectin and protects mice from diet-induced insulin resistance. American Journal of Physiology. Endocrinology and Metabolism 298 E28-E37. (doi:10.1152/ajpendo.00446.2009)

Arany Z, Lebrasseur N, Morris C, Smith E, Yang W, Ma Y, Chin S \& Spiegelman BM 2007 The transcriptional coactivator PGC-1 $\beta$ drives the formation of oxidative type IIX fibers in skeletal muscle. Cell Metabolism 5 35-46. (doi:10.1016/j.cmet.2006.12.003)

Baar K, Wende AR, Jones TE, Marison M, Nolte LA, Chen M, Kelly DP \& Holloszy JO 2002 Adaptations of skeletal muscle to exercise: rapid increase in the transcriptional coactivator PGC-1. FASEB Journal 16 1879-1886. (doi:10.1096/fj.02-0367com)

Barrès R, Yan J, Egan B, Treebak JT, Rasmussen M, Fritz T, Caidahl K, Krook A $\& \mathrm{O}^{\prime}$ Gorman DJ 2012 Acute exercise remodels promoter methylation in 
human skeletal muscle. Cell Metabolism 15 405-411. (doi:10.1016/ j.cmet.2012.01.001)

Bass J 2012 Circadian topology of metabolism. Nature 491 348-356. (doi:10.1038/nature11704)

Bassel-Duby R \& Olson EN 2006 Signaling pathways in skeletal muscle remodeling. Annual Review of Biochemistry 75 19-37. (doi:10.1146/ annurev.biochem.75.103004.142622)

Bergouignan A, Rudwill F, Simon C \& Blanc S 2011 Physical inactivity as the culprit of metabolic inflexibility: evidence from bed-rest studies. Journal of Applied Physiology 111 1201-1210. (doi:10.1152/japplphysiol. 00698.2011)

Bookout AL, Jeong Y, Downes M, Yu RT, Evans RM \& Mangelsdorf DJ 2006 Anatomical profiling of nuclear receptor expression reveals a hierarchical transcriptional network. Cell 126 789-799. (doi:10.1016/j.cell. 2006.06.049)

Braissant O, Foufelle F, Scotto C, Dauça M \& Wahli W 1996 Differential expression of peroxisome proliferator-activated receptors (PPARs): tissue distribution of PPAR- $\alpha,-\beta$, and $-\gamma$ in the adult rat. Endocrinology 137 354-366. (doi:10.1210/en.137.1.354)

Calvo JA, Daniels TG, Wang X, Paul A, Lin J, Spiegelman BM, Stevenson SC $\&$ Rangwala SM 2008 Muscle-specific expression of PPAR $\gamma$ coactivator$1 \alpha$ improves exercise performance and increases peak oxygen uptake. Journal of Applied Physiology 104 1304-1312. (doi:10.1152/japplphysiol. 01231.2007)

Cavaillès V, Dauvois S, L'Horset F, Lopez G, Hoare S, Kushner PJ \& Parker MG 1995 Nuclear factor Rip140 modulates transcriptional activation by the estrogen-receptor. EMBO Journal 14 3741-3751.

Chao LC, Zhang Z, Pei L, Saito T, Tontonoz P \& Pilch PF 2007 Nur77 coordinately regulates expression of genes linked to glucose metabolism in skeletal muscle. Molecular Endocrinology 21 2152-2163. (doi:10. 1210/me.2007-0169)

Chao LC, Wroblewski K, Ilkayeva OR, Stevens RD, Bain J, Meyer GA, SchenkS, Martinez L, Vergnes L, Narkar VA et al. 2012 Skeletal muscle Nur77 expression enhances oxidative metabolism and substrate utilization. Journal of Lipid Research 53 2610-2619. (doi:10.1194/jlr.M029355)

Chen J \& Nathans J 2007 Estrogen-related receptor $\beta /$ NR3B2 controls epithelial cell fate and endolymph production by the stria vascularis. Developmental Cell 13 325-337. (doi:10.1016/j.devcel.2007.07.011)

Chinsomboon J, Ruas J, Gupta RK, Thom R, Shoag J, Rowe GC, Sawada N, Raghuram S \& Arany Z 2009 The transcriptional coactivator PGC-1 $\alpha$ mediates exercise-induced angiogenesis in skeletal muscle. PNAS $\mathbf{1 0 6}$ 21401-21406. (doi:10.1073/pnas.0909131106)

Cho H, Zhao X, Hatori M, Yu RT, Barish GD, Lam MT, Chong LW, DiTacchio L, Atkins AR, Glass CK et al. 2012 Regulation of circadian behaviour and metabolism by REV-ERB- $\alpha$ and REV-ERB- $\beta$. Nature 485 123-127. (doi:10.1038/nature11048)

Christian M, White R \& Parker MG 2006 Metabolic regulation by the nuclear receptor corepressor RIP140. Trends in Endocrinology and Metabolism 17 243-250. (doi:10.1016/j.tem.2006.06.008)

DeFronzo RA, Jacot E, Jequier E, Maeder E, Wahren J \& Felber JP 1981 The effect of insulin on the disposal of intravenous glucose - results from indirect calorimetry and hepatic and femoral venous catheterization. Diabetes 30 1000-1007. (doi:10.2337/diab.30.12.1000)

Dressel U, Allen TL, Pippal JB, Rohde PR, Lau P \& Muscat GE 2003 The peroxisome proliferator-activated receptor $\beta / \delta$ agonist, GW501516, regulates the expression of genes involved in lipid catabolism and energy uncoupling in skeletal muscle cells. Molecular Endocrinology 17 2477-2493. (doi:10.1210/me.2003-0151)

Dufour CR, Wilson BJ, Huss JM, Kelly DP, Alaynick WA, Downes M, Evans RM, Blanchette $\mathrm{M}$ \& Giguère V 2007 Genome-wide orchestration of cardiac functions by the orphan nuclear receptors ERR $\alpha$ and $\gamma$. Cell Metabolism 5 345-356. (doi:10.1016/j.cmet.2007.03.007)

Eichner LJ \& Giguere V 2011 Estrogen related receptors (ERRs): a new dawn in transcriptional control of mitochondrial gene networks. Mitochondrion 11 544-552. (doi:10.1016/j.mito.2011.03.121)
Eudy JD, Yao S, Weston MD, Ma-Edmonds M, Talmadge CB, Cheng JJ, Kimberling WJ \& Sumegi J 1998 Isolation of a gene encoding a novel member of the nuclear receptor superfamily from the critical region of Usher syndrome type IIa at 1q41. Genomics 50 382-384. (doi:10.1006/ geno.1998.5345)

Evans RM, Barish GD \& Wang YX 2004 PPARs and the complex journey to obesity. Nature Medicine 10 355-361. (doi:10.1038/nm1025)

Fan W, Downes M, Atkins A, Yu R \& Evans RM 2011 Nuclear receptors and AMPK: resetting metabolism. Cold Spring Harbor Symposia on Quantitative Biology 76 17-22. (doi:10.1101/sqb.2012.76.010470)

Finck BN, Bernal-Mizrachi C, Han DH, Coleman T, Sambandam N, LaRiviere LL, Holloszy JO, Semenkovich CF \& Kelly DP 2005 A potential link between muscle peroxisome proliferator-activated receptor- $\alpha$ signaling and obesity-related diabetes. Cell Metabolism 1 133-144. (doi:10.1016/j.cmet.2005.01.006)

Foster C, Costill DL, Daniels JT \& Fink WJ 1978 Skeletal muscle enzyme activity, fiber composition and VO2 max in relation to distance running performance. European Journal of Applied Physiology and Occupational Physiology 39 73-80. (doi:10.1007/BF00421711)

Frier BC, Hancock CR, Little JP, Fillmore N, Bliss TA, Thomson DM, Wan Z \& Wright DC 2011 Reductions in RIP140 are not required for exerciseand AICAR-mediated increases in skeletal muscle mitochondrial content. Journal of Applied Physiology 111 688-695. (doi:10.1152/ japplphysiol.00279.2011)

Fujii N, Seifert MM, Kane EM, Peter LE, Ho RC, Winstead S, Hirshman MF \& Goodyear LJ 2007 Role of AMP-activated protein kinase in exercise capacity, whole body glucose homeostasis, and glucose transport in skeletal muscle - insight from analysis of a transgenic mouse model. Diabetes Research and Clinical Practice 77 S92-S98. (doi:10.1016/ j.diabres.2007.01.040)

Fujii N, Ho RC, Manabe Y, Jessen N, Toyoda T, Holland WL, Summers SA, Hirshman MF \& Goodyear LJ 2008 Ablation of AMP-activated protein kinase $\alpha 2$ activity exacerbates insulin resistance induced by high-fat feeding of mice. Diabetes 57 2958-2966. (doi:10.2337/db07-1187)

Gan Z, Burkart-Hartman EM, Han DH, Finck B, Leone TC, Smith EY, Ayala JE, Holloszy J \& Kelly DP 2011 The nuclear receptor PPAR $\beta / \delta$ programs muscle glucose metabolism in cooperation with AMPK and MEF2. Genes and Development 25 2619-2630. (doi:10.1101/gad.178434.111)

Gan Z, Rumsey J, Hazen BC, Lai L, Leone TC, Vega RB, Xie H, Conley KE, Auwerx J, Smith SR et al. 2013 Nuclear receptor/microRNA circuitry links muscle fiber type to energy metabolism. Journal of Clinical Investigation 123 2564-2575. (doi:10.1172/JCI67652)

Geng T, Li P, Okutsu M, Yin X, Kwek J, Zhang M \& Yan Z 2010 PGC-1 $\alpha$ plays a functional role in exercise-induced mitochondrial biogenesis and angiogenesis but not fiber-type transformation in mouse skeletal muscle. American Journal of Physiology. Cell Physiology 298 C572-C579. (doi:10.1152/ajpcell.00481.2009)

Giguère V, Yang N, Segui P \& Evans RM 1988 Identification of a new class of steroid hormone receptors. Nature 331 91-94. (doi:10.1038/331091a0)

Gollnick PD, Armstrong RB, Saubert CW IV, Piehl K \& Saltin B 1972 Enzyme-activity and fiber composition in skeletal-muscle of untrained and trained men. Journal of Applied Physiology 33 312-319.

Gollnick PD, Armstrong RB, Saltin B, Saubert CW IV, Sembrowich WL \& Shepherd RE 1973 Effect of training on enzyme activity and fiber composition of human skeletal muscle. Journal of Applied Physiology $\mathbf{3 4}$ 107-111.

Grazina R \& Massano J 2013 Physical exercise and Parkinson's disease: influence on symptoms, disease course and prevention. Reviews in the Neurosciences 24 139-152. (doi:10.1515/revneuro-2012-0087)

Hallberg M, Morganstein DL, Kiskinis E, Shah K, Kralli A, Dilworth SM, White R, Parker MG \& Christian M 2008 A functional interaction between RIP140 and PGC- $1 \alpha$ regulates the expression of the lipid droplet protein CIDEA. Molecular and Cellular Biology 28 6785-6795. (doi:10.1128/MCB.00504-08)

Hamilton MT \& Booth WF 2000 Booth skeletal muscle adaptation to exercise: a century of progress. Journal of Applied Physiology 88 327-331. 
Handschin C, Choi CS, Chin S, Kim S, Kawamori D, Kurpad AJ, Neubauer N, Hu J, Mootha VK, Kim YB et al. 2007 Abnormal glucose homeostasis in skeletal muscle-specific PGC- $1 \alpha$ knockout mice reveals skeletal musclepancreatic $\beta$ cell crosstalk. Journal of Clinical Investigation 117 3463-3474. (doi:10.1172/JCI31785)

Hardie DG 2007 AMP-activated/SNF1 protein kinases: conserved guardians of cellular energy. Nature Reviews. Molecular Cell Biology 8 774-785. (doi:10.1038/nrm2249)

He W, Barak Y, Hevener A, Olson P, Liao D, Le J, Nelson M, Ong E, Olefsky JM \& Evans RM 2003 Adipose-specific peroxisome proliferator-activated receptor $\gamma$ knockout causes insulin resistance in fat and liver but not in muscle. PNAS 100 15712-15717. (doi:10.1073/pnas.2536828100)

Heard DJ, Norby PL, Holloway J \& Vissing H 2000 Human ERR $\gamma$, a third member of the estrogen receptor-related receptor (ERR) subfamily of orphan nuclear receptors: tissue-specific isoforms are expressed during development and in the adult. Molecular Endocrinology 14 382-392. (doi:10.1210/me.14.3.382)

Hevener AL, He W, Barak Y, Le J, Bandyopadhyay G, Olson P, Wilkes J, Evans RM \& Olefsky J 2003 Muscle-specific Pparg deletion causes insulin resistance. Nature Medicine 9 1491-1497. (doi:10.1038/nm956)

Hickey MS, Carey JO, Azevedo JL, Houmard JA, Pories WJ, Israel RG \& Dohm GL 1995 Skeletal muscle fiber composition is related to adiposity and in vitro glucose transport rate in humans. American Journal of Physiology 268 E453-E457.

Hong H, Yang L \& Stallcup MR 1999 Hormone-independent transcriptional activation and coactivator binding by novel orphan nuclear receptor ERR3. Journal of Biological Chemistry 274 22618-22626. (doi:10.1074/ jbc.274.32.22618)

Hörlein AJ, Näär AM, Heinzel T, Torchia J, Gloss B, Kurokawa R, Ryan A, Kamei Y, Söderström M, Glass CK et al. 1995 Ligand-independent repression by the thyroid-hormone receptor-mediated by a nuclear receptor co-repressor. Nature 377 397-404. (doi:10.1038/377397a0)

Hu FB, Willett WC, Li T, Stampfer MJ, Colditz GA \& Manson JE 2004 Adiposity as compared with physical activity in predicting mortality among women. New England Journal of Medicine $3512694-2703$. (doi:10.1056/NEJMoa042135)

Huss JM, Kopp RP \& Kelly DP 2002 Peroxisome proliferator-activated receptor coactivator- $1 \alpha$ (PGC- $1 \alpha)$ coactivates the cardiac-enriched nuclear receptors estrogen-related receptor- $\alpha$ and $-\gamma-$ identification of novel leucine-rich interaction motif within PGC-1 $\alpha$. Journal of Biological Chemistry 277 40265-40274. (doi:10.1074/jbc.M206324200)

Huss JM, Torra IP, Staels B, Giguère V \& Kelly DP 2004 Estrogen-related receptor $\alpha$ directs peroxisome proliferator-activated receptor at signaling in the transcriptional control of energy metabolism in cardiac and skeletal muscle. Molecular and Cellular Biology 24 9079-9091. (doi:10. 1128/MCB.24.20.9079-9091.2004)

Issemann I \& Green S 1990 Activation of a member of the steroid hormone receptor superfamily by peroxisome proliferators. Nature 347 645-650. (doi:10.1038/347645a0)

Jäger S, Handschin C, St-Pierre J \& Spiegelman BM 2007 AMP-activated protein kinase (AMPK) action in skeletal muscle via direct phosphorylation of PGC-1 $\alpha$. PNAS 104 12017-12022. (doi:10.1073/ pnas.0705070104)

Jepsen K, Hermanson O, Onami TM, Gleiberman AS, Lunyak V, McEvilly RJ, Kurokawa R, Kumar V, Liu F, Seto E et al. 2000 Combinatorial roles of the nuclear receptor corepressor in transcription and development. Cell 102 753-763. (doi:10.1016/S0092-8674(00)00064-7)

Jin SM \& Youle RJ 2012 PINK1-and Parkin-mediated mitophagy at a glance. Journal of Cell Science 125 795-799. (doi:10.1242/jcs.093849)

Kamei Y, Ohizumi H, Fujitani Y, Nemoto T, Tanaka T, Takahashi N, Kawada T, Miyoshi M, Ezaki O \& Kakizuka A 2003 PPAR $\gamma$ coactivator $1 \beta /$ ERR ligand 1 is an ERR protein ligand, whose expression induces a highenergy expenditure and antagonizes obesity. PNAS 100 12378-12383. (doi:10.1073/pnas.2135217100)

Kersten S, Seydoux J, Peters JM, Gonzalez FJ, Desvergne B \& Wahli W 1999 Peroxisome proliferator-activated receptor $\alpha$ mediates the adaptive response to fasting. Journal of Clinical Investigation 103 1489-1498. (doi:10.1172/JCI6223)

Kliewer SA, Forman BM, Blumberg B, Ong ES, Borgmeyer U, Mangelsdorf DJ, Umesono K \& Evans RM 1994 Differential expression and activation of a family of murine peroxisome proliferator-activated receptors. PNAS 91 7355-7359. (doi:10.1073/pnas.91.15.7355)

Kressler D, Schreiber SN, Knutti D \& Kralli A 2002 The PGC-1-related protein PERC is a selective coactivator of estrogen receptor $\alpha$. Journal of Biological Chemistry 277 13918-13925. (doi:10.1074/jbc.M201134200)

Kumar N, Solt LA, Wang Y, Rogers PM, Bhattacharyya G, Kamenecka TM, Stayrook KR, Crumbley C, Floyd ZE, Gimble JM et al. 2010 Regulation of adipogenesis by natural and synthetic REV-ERB ligands. Endocrinology 151 3015-3025. (doi:10.1210/en.2009-0800)

de Lange P, Farina P, Moreno M, Ragni M, Lombardi A, Silvestri E, Burrone L, Lanni A \& Goglia F 2006 Sequential changes in the signal transduction responses of skeletal muscle following food deprivation. FASEB Journal 20 2579-2581. (doi:10.1096/fj.06-6025fje)

Lelliott CJ, Medina-Gomez G, Petrovic N, Kis A, Feldmann HM, Bjursell M, Parker N, Curtis K, Campbell M, Hu P et al. 2006 Ablation of PGC-1 $\beta$ results in defective mitochondrial activity, thermogenesis, hepatic function, and cardiac performance. PLoS Biology 4 e369. (doi:10.1371/ journal.pbio.0040369)

Lemanne D, Cassileth B \& Gubili J 2013 The role of physical activity in cancer prevention, treatment, recovery, and survivorship. Oncology 27 580-585.

Leonardsson G, Steel JH, Christian M, Pocock V, Milligan S, Bell J, So PW, Medina-Gomez G, Vidal-Puig A, White R et al. 2004 Nuclear receptor corepressor RIP140 regulates fat accumulation. PNAS 101 8437-8442. (doi:10.1073/pnas.0401013101)

Leone TC, Lehman JJ, Finck BN, Schaeffer PJ, Wende AR, Boudina S, Courtois M, Wozniak DF, Sambandam N, Bernal-Mizrachi C et al. 2005 PGC-1 $\alpha$ deficiency causes multi-system energy metabolic derangements: muscle dysfunction, abnormal weight control and hepatic steatosis. PLoS Biology 3 e101. (doi:10.1371/journal.pbio.0030101)

Lin J, Puigserver P, Donovan J, Tarr P \& Spiegelman BM 2002a Peroxisome proliferator-activated receptor $\gamma$ coactivator $1 \beta$ (PGC-1 $\beta$ ), a novel PGC1-related transcription coactivator associated with host cell factor. Journal of Biological Chemistry 277 1645-1648. (doi:10.1074/ jbc.C100631200)

Lin J, Wu H, Tarr PT, Zhang CY, Wu Z, Boss O, Michael LF, Puigserver P, Isotani $\mathrm{E}$, Olson $\mathrm{EN}$ et al. $2002 b$ Transcriptional co-activator PGC- $1 \alpha$ drives the formation of slow-twitch muscle fibres. Nature 418 797-801. (doi:10.1038/nature00904)

Luo J, Sladek R, Bader JA, Matthyssen A, Rossant J \& Giguère V 1997 Placental abnormalities in mouse embryos lacking the orphan nuclear receptor ERR- $\beta$. Nature 388 778-782. (doi:10.1038/42022)

Luo J, Sladek R, Carrier J, Bader JA, Richard D \& Giguère V 2003 Reduced fat mass in mice lacking orphan nuclear receptor estrogen-related receptor a. Molecular and Cellular Biology 23 7947-7956. (doi:10.1128/MCB.23. 22.7947-7956.2003)

Luquet S, Lopez-Soriano J, Holst D, Fredenrich A, Melki J, Rassoulzadegan M $\&$ Grimaldi PA 2003 Peroxisome proliferator-activated receptor $\delta$ controls muscle development and oxidative capability. FASEB Journal 17 2299-2301.

Mangelsdorf DJ, Thummel C, Beato M, Herrlich P, Schütz G, Umesono K, Blumberg B, Kastner P, Mark M, Chambon P et al. 1995 The nuclear receptor superfamily: the second decade. Cell $\mathbf{8 3} 835-839$. (doi:10. 1016/0092-8674(95)90199-X)

Matsakas A, Yadav V, Lorca S, Evans RM \& Narkar VA 2012 Revascularization of ischemic skeletal muscle by estrogen-related receptor- $\gamma$. Circulation Research 110 1087-1096. (doi:10.1161/CIRCRESAHA.112. 266478)

Matsakas A, Yadav V, Lorca S \& Narkar V 2013 Muscle ERR $\gamma$ mitigates Duchenne muscular dystrophy via metabolic and angiogenic reprogramming. FASEB Journal 27 4004-4016. (doi:10.1096/fj.13-228296)

Published by Bioscientifica Ltd 
Maxwell MA, Cleasby ME, Harding A, Stark A, Cooney GJ \& Muscat GE 2005 Nur77 regulates lipolysis in skeletal muscle cells - evidence for cross-talk between the $\beta$-adrenergic and an orphan nuclear hormone receptor pathway. Journal of Biological Chemistry 280 12573-12584. (doi:10.1074/jbc.M409580200)

Mellett LH \& Bousquet G 2013 Cardiology patient page. Heart-healthy exercise. Circulation 127 e571-e572. (doi:10.1161/CIRCULATIONAHA. 112.000880)

Mitsunaga K, Araki K, Mizusaki H, Morohashi K, Haruna K, Nakagata N, Giguère V, Yamamura K \& Abe K 2004 Loss of PGC-specific expression of the orphan nuclear receptor ERR- $\beta$ results in reduction of germ cell number in mouse embryos. Mechanisms of Development 121 237-246. (doi:10.1016/j.mod.2004.01.006)

Miyajima N, Horiuchi R, Shibuya Y, Fukushige S, Matsubara K, Toyoshima K \& Yamamoto T 1989 Two erbA homologs encoding proteins with different T3 binding capacities are transcribed from opposite DNA strands of the same genetic locus. Cell 57 31-39. (doi:10.1016/00928674(89)90169-4)

Mortensen OH, Frandsen L, Schjerling P, Nishimura E \& Grunnet N 2006 PGC- $1 \alpha$ and PGC-1 $\beta$ have both similar and distinct effects on myofiber switching toward an oxidative phenotype. American Journal of Physiology. Endocrinology and Metabolism 291 E807-E816. (doi:10.1152/ ajpendo.00591.2005)

Muoio DM, MacLean PS, Lang DB, Li S, Houmard JA, Way JM, Winegar DA, Corton JC, Dohm GL \& Kraus WE 2002 Fatty acid homeostasis and induction of lipid regulatory genes in skeletal muscles of peroxisome proliferator-activated receptor (PPAR) $\alpha$ knock-out mice. Evidence for compensatory regulation by PPAR $\delta$. Journal of Biological Chemistry 277 26089-26097. (doi:10.1074/jbc.M203997200)

Murray J \& Huss JM 2011 Estrogen-related receptor $\alpha$ regulates skeletal myocyte differentiation via modulation of the ERK MAP kinase pathway. American Journal of Physiology. Cell Physiology 301 C630-C645. (doi:10.1152/ajpcell.00033.2011)

Narendra D, Tanaka A, Suen DF \& Youle RJ 2008 Parkin is recruited selectively to impaired mitochondria and promotes their autophagy. Journal of Cell Biology 183 795-803. (doi:10.1083/jcb.200809125)

Narkar VA, Downes M, Yu RT, Embler E, Wang YX, Banayo E, Mihaylova MM, Nelson MC, Zou Y, Juguilon $\mathrm{H}$ et al. 2008 AMPK and PPAR $\delta$ agonists are exercise mimetics. Cell 134 405-415. (doi:10.1016/j.cell. 2008.06.051)

Narkar VA, Fan W, Downes M, Yu RT, Jonker JW, Alaynick WA, Banayo E, Karunasiri MS, Lorca S \& Evans RM 2011 Exercise and PGC- $1 \alpha-$ independent synchronization of type I muscle metabolism and vasculature by ERR $\gamma$. Cell Metabolism 13 283-293. (doi:10.1016/j.cmet. 2011.01.019)

Norris AW, Chen L, Fisher SJ, Szanto I, Ristow M, Jozsi AC, Hirshman MF, Rosen ED, Goodyear LJ, Gonzalez FJ et al. 2003 Muscle-specific PPAR $\gamma$-deficient mice develop increased adiposity and insulin resistance but respond to thiazolidinediones. Journal of Clinical Investigation 112 608-618

Oliver WR Jr, Shenk JL, Snaith MR, Russell CS, Plunket KD, Bodkin NL, Lewis MC, Winegar DA, Sznaidman ML, Lambert MH et al. 2001 A selective peroxisome proliferator-activated receptor $\delta$ agonist promotes reverse cholesterol transport. PNAS 98 5306-5311. (doi:10.1073/pnas. 091021198)

Onishi A, Peng GH, Poth EM, Lee DA, Chen J, Alexis U, de Melo J, Chen S \& Blackshaw S 2010 The orphan nuclear hormone receptor ERR $\beta$ controls rod photoreceptor survival. PNAS 107 11579-11584. (doi:10.1073/ pnas.1000102107)

Pearen MA \& Muscat GEO 2010 Minireview: Nuclear hormone receptor 4A signaling: implications for metabolic disease. Molecular Endocrinology 24 1891-1903. (doi:10.1210/me.2010-0015)

Pearen MA, Myers SA, Raichur S, Ryall JG, Lynch GS \& Muscat GE 2008 The orphan nuclear receptor, NOR-1, a target of $\beta$-adrenergic signaling, regulates gene expression that controls oxidative metabolism in skeletal muscle. Endocrinology 149 2853-2865. (doi:10.1210/ en.2007-1202)

Pearen MA, Eriksson NA, Fitzsimmons RL, Goode JM, Martel N, Andrikopoulos S \& Muscat GE 2012 The nuclear receptor, Nor-1, markedly increases type II oxidative muscle fibers and resistance to fatigue. Molecular Endocrinology 26 372-384. (doi:10.1210/me.2011-1274)

Pérez-Schindler J, Summermatter S, Salatino S, Zorzato F, Beer M, Balwierz PJ, van Nimwegen E, Feige JN, Auwerx J \& Handschin C 2012 The corepressor NCoR1 antagonizes PGC- $1 \alpha$ and estrogen-related receptor $\alpha$ in the regulation of skeletal muscle function and oxidative metabolism. Molecular and Cellular Biology 32 4913-4924. (doi:10.1128/МСB. 00877-12)

Perseghin G, Price TB, Petersen KF, Roden M, Cline GW, Gerow K, Rothman DL \& Shulman GI 1996 Increased glucose transportphosphorylation and muscle glycogen synthesis after exercise training in insulin-resistant subjects. New England Journal of Medicine 335 1357-1362. (doi:10.1056/NEJM199610313351804)

Potthoff MJ, Wu H, Arnold MA, Shelton JM, Backs J, McAnally J, Richardson JA, Bassel-Duby R \& Olson EN 2007 Histone deacetylase degradation and MEF2 activation promote the formation of slowtwitch myofibers. Journal of Clinical Investigation 117 2459-2467. (doi:10.1172/JCI31960)

Preitner N, Damiola F, Lopez-Molina L, Zakany J, Duboule D, Albrecht U \& Schibler U 2002 The orphan nuclear receptor REV-ERB $\alpha$ controls circadian transcription within the positive limb of the mammalian circadian oscillator. Cell 110 251-260. (doi:10.1016/ S0092-8674(02)00825-5)

Puigserver P, Wu Z, Park CW, Graves R, Wright M \& Spiegelman BM 1998 A cold-inducible coactivator of nuclear receptors linked to adaptive thermogenesis. Cell 92 829-839. (doi:10.1016/S0092-8674(00)81410-5)

Puigserver P, Rhee J, Lin J, Wu Z, Yoon JC, Zhang CY, Krauss S, Mootha VK, Lowell BB \& Spiegelman BM 2001 Cytokine stimulation of energy expenditure through $\mathrm{p} 38$ MAP kinase activation of PPAR $\gamma$ coactivator-1. Molecular Cell 8 971-982. (doi:10.1016/S1097-2765(01)00390-2)

Raghuram S, Stayrook KR, Huang P, Rogers PM, Nosie AK, McClure DB, Burris LL, Khorasanizadeh S, Burris TP \& Rastinejad F 2007 Identification of heme as the ligand for the orphan nuclear receptors REV-ERB $\alpha$ and REV-ERBB. Nature Structural \& Molecular Biology 14 1207-1213. (doi:10.1038/nsmb1344)

Rangwala SM, Wang X, Calvo JA, Lindsley L, Zhang Y, Deyneko G, Beaulieu V, Gao J, Turner G \& Markovits J 2010 Estrogen-related receptor $\gamma$ is a key regulator of muscle mitochondrial activity and oxidative capacity. Journal of Biological Chemistry 285 22619-22629. (doi:10.1074/jbc. M110.125401)

Rodgers JT, Lerin C, Haas W, Gygi SP, Spiegelman BM \& Puigserver P 2005 Nutrient control of glucose homeostasis through a complex of PGC-1 $\alpha$ and SIRT1. Nature 434 113-118. (doi:10.1038/nature03354)

van Rooij E, Quiat D, Johnson BA, Sutherland LB, Qi X, Richardson JA, Kelm RJ Jr \& Olson EN 2009 A family of microRNAs encoded by myosin genes governs myosin expression and muscle performance. Developmental Cell 17 662-673. (doi:10.1016/j.devcel.2009.10.013)

Rowe GC, El-Khoury R, Patten IS, Rustin P \& Arany Z 2012 PGC- $1 \alpha$ is dispensable for exercise-induced mitochondrial biogenesis in skeletal muscle. PLOS ONE 7 e41817. (doi:10.1371/journal.pone.0041817)

Russell AP, Feilchenfeldt J, Schreiber S, Praz M, Crettenand A, Gobelet C, Meier CA, Bell DR, Kralli A, Giacobino JP et al. 2003 Endurance training in humans leads to fiber type-specific increases in levels of peroxisome proliferator-activated receptor- $\gamma$ coactivator- 1 and peroxisome proliferator-activated receptor- $\alpha$ in skeletal muscle. Diabetes $\mathbf{5 2} 2874-2881$. (doi:10.2337/diabetes.52.12.2874)

Sanyal S, Matthews J, Bouton D, Kim HJ, Choi HS, Treuter E \& Gustafsson JA 2004 Deoxyribonucleic acid response element-dependent regulation of transcription by orphan nuclear receptor estrogen receptor-related receptor $\gamma$. Molecular Endocrinology 18 312-325. (doi:10.1210/me. 2003-0165) 
Schiaffino S \& Reggiani C 2011 Fiber types in mammalian skeletal muscles. Physiological Reviews 91 1447-1531. (doi:10.1152/physrev.00031.2010)

Schuler MJ, Bühler S \& Pette D 1999 Effects of contractile activity and hypothyroidism on nuclear hormone receptor mRNA isoforms in rat skeletal muscle. European Journal of Biochemistry 264 982-988. (doi:10.1046/j.1432-1327.1999.00706.x)

Schuler M, Ali F, Chambon C, Duteil D, Bornert JM, Tardivel A, Desvergne B, Wahli W, Chambon P \& Metzger D 2006 PGC1 $\alpha$ expression is controlled in skeletal muscles by PPAR $\beta$, whose ablation results in fiber-type switching, obesity, and type 2 diabetes. Cell Metabolism 4 407-414. (doi:10.1016/j.cmet.2006.10.003)

Seth A, Steel JH, Nichol D, Pocock V, Kumaran MK, Fritah A, Mobberley M, Ryder TA, Rowlerson A, Scott J et al. 2007 The transcriptional corepressor RIP140 regulates oxidative metabolism in skeletal muscle. Cell Metabolism 6 236-245. (doi:10.1016/j.cmet.2007.08.004)

Solt LA, Wang Y, Banerjee S, Hughes T, Kojetin DJ, Lundasen T, Shin Y, Liu J, Cameron MD, Noel R et al. 2012 Regulation of circadian behaviour and metabolism by synthetic REV-ERB agonists. Nature $\mathbf{4 8 5}$ 62-68. (doi:10. 1038/nature11030)

Sonoda J, Mehl IR, Chong LW, Nofsinger RR \& Evans RM 2007 PGC-1ß controls mitochondrial metabolism to modulate circadian activity, adaptive thermogenesis, and hepatic steatosis. PNAS 104 5223-5228. (doi:10.1073/pnas.0611623104)

Teyssier C, Ma H, Emter R, Kralli A \& Stallcup MR 2005 Activation of nuclear receptor coactivator PGC- $1 \alpha$ by arginine methylation. Genes and Development 19 1466-1473. (doi:10.1101/gad.1295005)

Villena JA, Hock MB, Chang WY, Barcas JE, Giguère V \& Kralli A 2007 Orphan nuclear receptor estrogen-related receptor $\alpha$ is essential for adaptive thermogenesis. PNAS 104 1418-1423. (doi:10.1073/pnas. 0607696104)

Wang YX, Zhang CL, Yu RT, Cho HK, Nelson MC, Bayuga-Ocampo CR, Ham J, Kang H \& Evans RM 2004 Regulation of muscle fiber type and running endurance by PPARס. PLoS Biology 2 e294. (doi:10.1371/ journal.pbio.0020294)

Watt MJ, Southgate RJ, Holmes AG \& Febbraio MA 2004 Suppression of plasma free fatty acids upregulates peroxisome proliferator-activated receptor (PPAR) $\alpha$ and $\delta$ and PPAR coactivator $1 \alpha$ in human skeletal muscle, but not lipid regulatory genes. Journal of Molecular Endocrinology 33 533-544. (doi:10.1677/jme.1.01499)

Wende AR, Huss JM, Schaeffer PJ, Giguère V \& Kelly DP 2005 PGC- $1 \alpha$ coactivates PDK4 gene expression via the orphan nuclear receptor ERR $\alpha$ : a mechanism for transcriptional control of muscle glucose metabolism. Molecular and Cellular Biology 25 10684-10694. (doi:10. 1128/MCB.25.24.10684-10694.2005)

Woldt E, Sebti Y, Solt LA, Duhem C, Lancel S, Eeckhoute J, Hesselink MK, Paquet C, Delhaye S, Shin Y et al. 2013 Rev-erb- $\alpha$ modulates skeletal muscle oxidative capacity by regulating mitochondrial biogenesis and autophagy. Nature Medicine 19 1039-1046. (doi:10.1038/nm.3213)

Wu Z, Puigserver P, Andersson U, Zhang C, Adelmant G, Mootha V, Troy A, Cinti S, Lowell B, Scarpulla RC et al. 1999 Mechanisms controlling mitochondrial biogenesis and respiration through the thermogenic coactivator PGC-1. Cell 98 115-124. (doi:10.1016/S00928674(00)80611-X)
Wu H, Rothermel B, Kanatous S, Rosenberg P, Naya FJ, Shelton JM, Hutcheson KA, DiMaio JM, Olson EN, Bassel-Duby R et al. 2001 Activation of MEF2 by muscle activity is mediated through a calcineurin-dependent pathway. EMBO Journal $206414-6423$. (doi:10.1093/emboj/20.22.6414)

Wurtz JM, Bourguet W, Renaud JP, Vivat V, Chambon P, Moras D \& Gronemeyer H 1996 A canonical structure for the ligand-binding domain of nuclear receptors. Nature Structural Biology 3 87-94. (doi:10. 1038/nsb0196-87)

Xie W, Hong H, Yang NN, Lin RJ, Simon CM, Stallcup MR \& Evans RM 1999 Constitutive activation of transcription and binding of coactivator by estrogen-related receptors 1 and 2. Molecular Endocrinology 13 21512162. (doi:10.1210/me.13.12.2151)

Yamamoto H, Williams EG, Mouchiroud L, Cantó C, Fan W, Downes M, Héligon C, Barish GD, Desvergne B, Evans RM et al. 2011 NCoR1 is a conserved physiological modulator of muscle mass and oxidative function. Cell 147 827-839. (doi:10.1016/j.cell.2011.10.017)

Yan Z, Okutsu M, Akhtar YN \& Lira VA 2011 Regulation of exercise-induced fiber type transformation, mitochondrial biogenesis, and angiogenesis in skeletal muscle. Journal of Applied Physiology 110 264-274. (doi:10. 1152/japplphysiol.00993.2010)

Yang X, Downes M, Yu RT, Bookout AL, He W, Straume M, Mangelsdorf DJ \& Evans RM 2006 Nuclear receptor expression links the circadian clock to metabolism. Cell 126 801-810. (doi:10.1016/j.cell.2006.06.050)

Yin L, Wu N, Curtin JC, Qatanani M, Szwergold NR, Reid RA, Waitt GM, Parks DJ, Pearce KH, Wisely GB et al. 2007 Rev-erb $\alpha$, a heme sensor that coordinates metabolic and circadian pathways. Science 318 1786-1789. (doi:10.1126/science.1150179)

Zechner C, Lai L, Zechner JF, Geng T, Yan Z, Rumsey JW, Collia D, Chen Z, Wozniak DF, Leone TC et al. 2010 Total skeletal muscle PGC-1 deficiency uncouples mitochondrial derangements from fiber type determination and insulin sensitivity. Cell Metabolism 12 633-642. (doi:10.1016/j.cmet.2010.11.008)

Zhang ZP \& Teng CT 2000 Estrogen receptor-related receptor $\alpha 1$ interacts with coactivator and constitutively activates the estrogen response elements of the human lactoferrin gene. Journal of Biological Chemistry 275 20837-20846. (doi:10.1074/jbc.M001880200)

Zhu Y, Alvares K, Huang Q, Rao MS \& Reddy JK 1993 Cloning of a new member of the peroxisome proliferator-activated receptor gene family from mouse liver. Journal of Biological Chemistry 268 26817-26820.

Zong H, Ren JM, Young LH, Pypaert M, Mu J, Birnbaum MJ \& Shulman GI 2002 AMP kinase is required for mitochondrial biogenesis in skeletal muscle in response to chronic energy deprivation. PNAS 99 15983-15987. (doi:10.1073/pnas.252625599)

Zuercher WJ, Gaillard S, Orband-Miller LA, Chao EY, Shearer BG, Jones DG, Miller AB, Collins JL, McDonnell DP \& Willson TM 2005 Identification and structure-activity relationship of phenolic acyl hydrazones as selective agonists for the estrogen-related orphan nuclear receptors ERR $\beta$ and ERR $\gamma$. Journal of Medicinal Chemistry 48 3107-3109. (doi:10. 1021/jm050161j)

Zurlo F, Larson K, Bogardus C \& Ravussin E 1990 Skeletal-muscle metabolism is a major determinant of resting energy-expenditure. Journal of Clinical Investigation 86 1423-1427. (doi:10.1172/JCI114857)

Received in final form 31 October 2013

Accepted 1 November 2013 http://jme.endocrinology-journals.org DOI: 10.1530/JME-13-0258
() 2013 Society for Endocrinology Printed in Great Britain
Published by Bioscientifica Ltd 